\title{
Financial Intermediation and Economic Growth in Cameroon
}

\author{
Ibrahim Ngouhouo ${ }^{1} \&$ Giscard Moutie ${ }^{2}$ \\ ${ }^{1}$ Assistant Professor of Economic Analysis and Policy, FSEG, Dschang University, Dschang, Cameroon \\ ${ }^{2}$ Ph.D Student of Economic Analysis and Policy, FSEG, Dschang University, Dschang, Cameroon \\ Correspondence: Ibrahim Ngouhouo, Assistant Professor of Economic Analysis and Policy, FSEG, Dschang \\ University, P. O. Box 110 Dschang, Cameroon. E-mail: ngouhouo@yahoo.fr
}

Received: June 29, 2015

Accepted: July 7, 2015

Online Published: July 16, 2015

doi:10.5430/ijfr.v6n3p143

URL: http://dx.doi.org/10.5430/ijfr.v6n3p143

\begin{abstract}
Cameroonian economic policy from 1988 restructured the financial sector towards a greater Financial Intermediation (FI). This article seeks to understand the nature of the link between FI and Economic Growth. In order to acheive this main objective, the relationship between FI components and economic growth measured by GNP per capita is modeled by a Vector Auto Regression model using secondary data for the period 1977 to 2006. The study shows no causal effect between FI and growth and vice versa. This could be explained by the restructuring of the banking system, bank overliquidity, Micro Finance Establishment's instability and the poor growth environment. Thus banks and Micro Finance Establishments (MFE) might consolidate their management system in order to ensure their credibility as well as their continuity. The Banking Commission of Central Africa (COBAC) and the Cameroonian government should intensify the process of the stabilization of the micro finance sector and create a credible financial market.
\end{abstract}

Keywords: bank, micro finance establishments, credit, saving

\section{Introduction}

At the beginning of the 1960's, all the African countries beyond the political ideologies were confronted with the choice of development strategy. These development strategies (Planning and Structural Adjustment Plan) carried out under the impulse of the international institutions (World Bank, International Monetary Fund, African Development Bank) were based on the stimulation of the growth through investments, taking into account the financial component. After the fall of the oil prices and raw materials, the 1980s witnessed a massive debt of the developing countries. The Cameroonian economic policy since 1988 has restructured the financial sector towards a greater financial intermediation with the advent of structural adjustment and the promulgation of the 1990 and 1992 laws related to cooperative companies and common initiatives groups. Thus many cooperatives were created $\mathrm{MC}^{2}$, MUFFA, Cofinest) in order to satisfy the marginalized population from classical banks. Taking into consideration the fact that, in any liberal economy, a well developed financial sector promotes economic activities, domestic investment and accumulation of wealth through credits and cost reduction of financial intermediation, we can say that Financial Intermediation (FI) has a special effect on Economic growth in Cameroon. Within this context, this article titled "Financial Intermediation (FI) and Economic growth in Cameroon" aims to understand the nature of the link between FI and Economic Growth in Cameroun.

\section{Literature Review}

\subsection{Theoretical Literature}

Many theories exist on the relationship between Financial Intermediation and Economic Growth. These include: the theory of Financial Intermediation, the theory of financial liberalization, the theory of endogenous growth and that of microfinance and economic growth. Financial Intermediation is an activity through which an institutional unit acquires financial credit and simultaneously, contracts engagements on its own account by means of financial transactions on the market (Biales, 2006). Financial Intermediation has certain characteristics, among those, we can quote the three most important: (1) the fact that it is based on two bilateral relations: on one hand between the non-financial agent or the borrower and the financial intermediary and on the other hand between this intermediary and the source of financing used; (2) the fact that it supposes exchanges of information at the individual level whereas at the level of market information, it is collective and (3) the rate of intermediation which measures the 
share of the finances brought by the financial agents as a ratio of the finances from which the non-financial agents benefit. In a historitical way, we distinguish two types of intermediation; one in the broad sense and another in a strict sense. The first results from an approach known as the supply from financing because it gathers under the label of intermediate finances the whole of the contests granted to the non-financial agents by all the financial institutions. This rate calculated thus brings down the whole finances in which various institutions take part on the total of non-financial finances granted to agents. The second rate results from an approach known as the demand for financing because it privileges the choice that applicant made with the profit of recourse to financial intermediaries.

At the beginning of the seventies, the concept of financial liberalization appeared with the work of McKinnon and Shaw (1973) whose analysis aimed at showing that within the framework of an economy in which financial repression exist, the fixing of the interest rates below their value of balance reduces saving, fixes investment below its optimal level and deteriorates the quality. In this context, financial liberalization (rise of real interest rate) will increase saving and thus will allow investment's growth. As title of recall, financial repression can be defined as being the various interventions of the government on financial sector (a raised of obligatory reserve or fixing of interest rate). According to this theory, financial liberalization is a simple and effective means to accelerate economic growth in the developing countries. International organizations (International Monetary Fund and World Bank) as well as several developing countries were allured by this theory so that, as of the middle of seventies, a certain number of countries set up the process of financial liberalization.

This theory born in the years 1990, supposes that the returns to scale are increasing while capital (finance) and knowledge are endogenous. The third factor taken into account to explain Growth $(\mathrm{C})$ is, according to different versions of this theory, human capital, research and development or public capital.

The World Bank estimates that approximately a billion people throughout the world live in poverty but several million of them would be able to develop businesses if they could reach financial services. In fact according to Christen et al.. (2006), microcredit programs make it possible for the poor to create employment by developing small projects and help each other mutually to leave their state of poverty. Moreover, other services accompaying these programs have significant effects on the socio-economic life of the served populations: mobilization of the saving and training given to the poor. Furthermore, according to Marion (1990) "microentrepreneurs do not need subsidies, but of a fast and less constraining access to services adapted to their needs and to the local context (...)".

Microcredit thus constitutes a powerful instrument of the fight against poverty since it makes it possible for the poor to increase their incomes and improve their living conditions, increase their productivity and their efficiency, develop microbusinesses, (...) and reduce the risks to which they are exposed. Therefore, the successes obtained as regards the supply of financial services to the poor give a glimmer of hope to the development organisations, governments, stakeholders and recipients. As an example, we can quote the Grameen Bank in Bangladesh which developed a very popular model reproduced in several countries of the world. However, microcredit must find a compromise between the viability of the institution and accessibility to a greater number of the poor. In fact, the impact of microfinance on growth thus passes through the fight against poverty so that the underprivileged people can survive and undertake small economic activities. But what becomes the customers whose MFE close after a relatively short lifespan like Cofinest and Godly Business Funds?

\subsection{Empirical Literature}

The empirical relationship between the development of the financial sector and the economic growth is more solid. There is now a wide literature which justifies this relationship with the use of a large variety of data (Khan, 2000 and Levine, 1996). The hypothesis capitalization helps growth has been around for several years but a firm demonstration appears only in the year 1990 .

The study by Goldsmith (1969) on the relationship between economic growth and the measures of the correct functions of the financial system uses the value of credit of FI relating to the GDP to measure the financial development; under the assumption that the size of the financial system is positively correlated with openness and the quality of financial services. Using data on 35 countries from 1860 to 1963, Goldsmith arrives at the following result: there exists an approximate parallelism between economic development and financial development for several decades; the fact that periods of faster economic growth are accompanied by financial development. The work of Goldsmith presents some weaknesses: The use of observations only limited to 35 countries; the lack of control of other factors which affect economic growth (Levine and Renelt, 1992); absence of analysis as for the fact if financial development is associated to the growth of the productivity and to the accumulation of the capital; the possibility that the size of the FI does not measure in a suitable way the operation of the financial system and the narrow association 
between the size of the financial system and the economic growth does not identify the direction of causality (Barro and Salt-I-Martin, 1996).

Goldsmith (1969) is one of the first economists to show the interrelationship between financial development and economic growth by using data of 35 countries (developed and under developed) from 1860 to 1963 . By measuring financial development by the total Financial credit ratio on GDP, it showed that this ratio is positively correlated with economic growth. However, the study didn't take into account other factors which could affect economic growth.

Later, the study of King and Levine (1993) under the title "Finance and Growth: Schumpeter Might Be bearing Right "on a sample of 80 countries (developed and under developed) over the period 1960 to 1989 showed that the bivariate analysis reveals a strong positive correlation between financial development and growth. In addition, in the multivariate analysis, the results remain significant even after having included various variables which influence the economic growth.

Then Roubini and Salt-I-Martin (1992) made studies on cross section and showed that financial development has a positive effect on GDPs growth rate after having controlled the influence of various factors which can affect growth like education, inflation or political stability. However this correlation between financial development and economic growth depends on the countries considered. These results suggest that Financial Intermediation can have a significant effect in developing countries. No study has been done in Cameroon and therefore it is necessary to investigate its situation with a different methodology.

\section{Methodology}

\subsection{Data and Sources}

In order to attain this main objective, we use secondary datas such as Gross Domestic Product, Private credits, monetary mass and Intermediation margin collected from BEAC, COBAC, the International Monetary Fund, Camcull and the $\mathrm{MC}^{2}$ network headquarters in Cameroon and the National accounting board of Cameroon statistics using data for the period 1977 to 2006.

\subsection{Modeling the Relationship between Financial Intermediation and Economic Growth}

The relationship between FI components and economic growth is modeled by the Vector Auto Regression (VAR) model which captures the main problems of endogeneity and causality. Under the fundamental hypothesis that Financial Intermediation causes Economic growth, we define a certain number of variables justified on theoretical basis. We thus retained as endogenous variables representative of the concepts of economic growth and Financial Intermediation, the GDP per capita noted LGDP, the logarithm of private credits (LCcmlt), the logarithm of monetary mass (LM2) and the logarithm of Intermediation margin (LMi). Exogenous variables are constant variable and the lag variables. From our variables coded above, we obtain a model to be estimated as:

$$
\left(\begin{array}{c}
\mathrm{LPib}_{t} \\
\mathrm{LCcmlt}_{t} \\
\mathrm{LM}_{t} \\
\mathrm{LMi}_{t}
\end{array}\right)=\left(\begin{array}{ccccc}
a_{0} & a_{1} & a_{2} & a_{3} & a_{4} \\
b_{0} & b_{1} & b_{2} & b_{3} & b_{4} \\
c_{0} & c_{1} & c_{2} & c_{3} & c_{4} \\
d_{0} & d_{1} & d_{2} & d_{3} & d_{4}
\end{array}\right)\left(\begin{array}{c}
1 \\
\mathrm{LPib}_{t-p} \\
\mathrm{LCcmlt}_{t-p} \\
\mathrm{LM}_{t-p} \\
\mathrm{LMi}_{t-p}
\end{array}\right)+\left(\begin{array}{c}
\varepsilon_{1 t} \\
\varepsilon_{2 t} \\
\varepsilon_{3 t} \\
\varepsilon_{4 t}
\end{array}\right)
$$

With $\mathrm{t}=1977 \ldots, 2006 ; \mathrm{n}=30$ observations; $\mathrm{a}_{0} \ldots{ }_{4} ; \mathrm{b}_{0} \ldots{ }_{4} ; \mathrm{c}_{0} \ldots{ }_{4} ; \mathrm{d}_{0} \ldots{ }_{4}$ parameters of the model comparable to the coefficients of regression.

\section{Results and Interpretations}

We use the stationnarity test of Dickey-Fuller and the test of AIC (Akaike Information Criteria) to determine the number of lags, the estimation of the VAR model and finally the study of causality by the method of Toda-Yamamoto.

\subsection{Results and Interpretation of the Tests of Stationnarity}

When time series data is used, it is first of all important that they preserve a constant distribution in time. As far as we are using the methodology of Toda-Yamamoto (1995), wether our variables (LPibr, LCcmlt, LM2 and LMi) are stationary or not, we can thus carry out the model's estimation. 


\subsection{Results and Interpretation of the VAR Model Estimated}

To determine the lag, we used AIC, HQ and SC criteria. We find that the minimum lag is $\mathrm{k}=1$. Thus according to the assumption of the test of Toda-Yamamoto, the lag is $\mathrm{p}=\mathrm{k}+1$ i.e. $\mathrm{p}=2$. Only the test of information of Akaike (AIC) is taken into account, which enables us to carry out the estimation.

Table 1. Estimation of the VAR model

\begin{tabular}{|c|c|c|c|c|}
\hline & LOGPIB (I) & LOGCCM (II) & LOGMI (III) & LOGM2 (IV) \\
\hline LOGPIB(-1) & $\begin{array}{r}0.740047 \\
(0.29471) \\
{[2.51107]}\end{array}$ & $\begin{array}{c}0.025226 \\
(0.18855) \\
{[0.13379]}\end{array}$ & $\begin{array}{r}0.030316 \\
(0.04830) \\
{[0.62761]}\end{array}$ & $\begin{array}{c}0.005714 \\
(0.01243) \\
{[0.45970]}\end{array}$ \\
\hline LOGPIB(-2) & $\begin{array}{c}3.855238 \\
(4.20259) \\
{[0.91735]}\end{array}$ & $\begin{array}{c}0.624958 \\
(2.68865) \\
{[0.23244]}\end{array}$ & $\begin{array}{r}1.424377 \\
(0.68880) \\
{[2.06791]}\end{array}$ & $\begin{array}{c}0.156572 \\
(0.17725) \\
{[0.88332]}\end{array}$ \\
\hline LOGCCM(-1) & $\begin{array}{c}-0.145055 \\
(0.46468) \\
{[-0.31216]}\end{array}$ & $\begin{array}{c}0.429352 \\
(0.29728) \\
{[1.44426]}\end{array}$ & $\begin{array}{r}-0.067276 \\
(0.07616) \\
{[-0.88335]}\end{array}$ & $\begin{array}{c}-0.005842 \\
(0.01960) \\
{[-0.29806]}\end{array}$ \\
\hline LOGCCM(-2) & $\begin{array}{c}-3.634295 \\
(4.20035) \\
{[-0.86524]}\end{array}$ & $\begin{array}{r}-0.653059 \\
(2.68722) \\
{[-0.24302]}\end{array}$ & $\begin{array}{c}-1.434860 \\
(0.68843) \\
{[-2.08424]}\end{array}$ & $\begin{array}{r}-0.178249 \\
(0.17716) \\
{[-1.00615]}\end{array}$ \\
\hline LOGMI(-1) & $\begin{array}{r}-0.683945 \\
(1.28856) \\
{[-0.53078]}\end{array}$ & $\begin{array}{c}-0.200441 \\
(0.82437) \\
{[-0.24314]}\end{array}$ & $\begin{array}{c}0.887778 \\
(0.21119) \\
{[4.20361]}\end{array}$ & $\begin{array}{r}-0.055636 \\
(0.05435) \\
{[-1.02369]}\end{array}$ \\
\hline LOGMI(-2) & $\begin{array}{c}-0.404261 \\
(1.35932) \\
{[-0.29740]}\end{array}$ & $\begin{array}{c}-0.108141 \\
(0.86964) \\
{[-0.12435]}\end{array}$ & $\begin{array}{c}-0.350202 \\
(0.22279) \\
{[-1.57188]}\end{array}$ & $\begin{array}{c}0.052662 \\
(0.05733) \\
{[0.91854]}\end{array}$ \\
\hline LOGM2(-1) & $\begin{array}{c}-0.920012 \\
(5.26517) \\
{[-0.17474]}\end{array}$ & $\begin{array}{r}1.706477 \\
(3.36845) \\
{[0.50661]}\end{array}$ & $\begin{array}{c}0.492173 \\
(0.86296) \\
{[0.57033]}\end{array}$ & $\begin{array}{r}0.738394 \\
(0.22207) \\
{[3.32504]}\end{array}$ \\
\hline LOGM2(-2) & $\begin{array}{r}-0.400877 \\
(6.17925) \\
{[-0.06487]}\end{array}$ & $\begin{array}{c}0.088089 \\
(3.95324) \\
{[0.02228]}\end{array}$ & $\begin{array}{r}1.185546 \\
(1.01277) \\
{[1.17060]}\end{array}$ & $\begin{array}{c}0.311381 \\
(0.26062) \\
{[1.19475]}\end{array}$ \\
\hline C & $\begin{array}{r}34.89327 \\
(35.9158) \\
{[0.97153]}\end{array}$ & $\begin{array}{c}-10.32133 \\
(22.9775) \\
{[-0.44919]}\end{array}$ & $\begin{array}{r}-12.07760 \\
(5.88655) \\
{[-2.05173]}\end{array}$ & $\begin{array}{r}0.018287 \\
(1.51483) \\
{[0.01207]}\end{array}$ \\
\hline $\mathbf{R}^{2}$ & 0.532468 & 0.541571 & 0.901858 & 0.904425 \\
\hline Ajusted $R^{2}$ & 0.335612 & 0.348548 & 0.860535 & 0.864183 \\
\hline F-statistic & 2.704862 & 2.805734 & 21.82455 & 22.47456 \\
\hline
\end{tabular}

NB: - figures without brackets represent the coefficient of the variables

- figures in brackets represent the standard errors.

- figures in [ ] represent the value of t-student.

- C: is the constant.

The VAR model estimated above has a good fit. The $\mathrm{R}^{2}$ is more than $70 \%$ in general and the adjusted $\mathrm{R}^{2}$ with a value of more than $60 \%$ in average. Furthermore, the F- statistic is globally significant. Referring to the coefficients signs, GDP and M2 vary in the same direction with private credits citeris paribus. Only intermediation margin varies in the 
opposite direction with credits, which means that when intermediation margin increases, credits decrease which is not normal in practice. In fact the increase of Mi should instead stimulate banks and MFE to grant more credits. This situation could be explained by poor growth environment, research of guaranteed and slowness of the feasibility study of projects.

\subsection{Results and Interpretation of the Causality Test}

From the increasing interdependence between the variables, it arises from the literature that economic growth causes Financial Intermediation; that Financial Intermediation causes to a certain extent economic growth and without forgetting the debate according to which there exist a bi-directional link between economic growth and Financial Intermediation. Several tests are performed to test the causality between the variables, but within the framework of our study, the tests of causality according to Toda-Yamamoto used are represented in the table below.

Table 2. Results of the test of causality

\begin{tabular}{lcccl}
\hline Variables & $\begin{array}{c}\text { Number of } \\
\text { observations }\end{array}$ & Khi-2 & Probabilities & Decisions \\
\hline $\mathrm{CCM} \rightarrow$ GDP & 28 & 0.828246 & 0.6609 & NO \\
\hline $\mathrm{M} 2 \rightarrow$ GDP & 28 & 0.124055 & 0.9399 & NO \\
\hline $\mathrm{MI} \rightarrow \mathrm{GDP}$ & 28 & 1.182932 & 0.5535 & NO \\
\hline $\mathrm{GDP} \rightarrow \mathrm{CCM}$ & 28 & 0.065555 & 0.9678 & NO \\
\hline $\mathrm{GDP} \rightarrow \mathrm{M} 2$ & 28 & 0.909067 & 0.6347 & NO \\
\hline $\mathrm{GDP} \rightarrow \mathrm{MI}$ & 28 & 4.427219 & 0.1093 & NO \\
\hline $\mathrm{M} 2 \rightarrow \mathrm{CCM}$ & 28 & 0.654288 & 0.7210 & NO \\
\hline $\mathrm{MI} \rightarrow \mathrm{CCM}$ & 28 & 0.233915 & 0.8896 & NO \\
\hline $\mathrm{CCM} \rightarrow \mathrm{M} 2$ & 28 & 1.081577 & 0.5823 & NO \\
\hline $\mathrm{MI} \rightarrow \mathrm{M} 2$ & 28 & 1.124322 & 0.5700 & NO \\
\hline $\mathrm{CCM} \rightarrow \mathrm{MI}$ & 28 & 5.002027 & 0.0820 & YES \\
\hline $\mathrm{M} 2 \rightarrow \mathrm{MI}$ & 28 & 6.470339 & 0.0394 & YES \\
\hline
\end{tabular}

We can see from Table 2 that there is an uni-directional causality from credits to intermediation margin and from monetary mass to intermediation margin. This is due to the fact that profits realised by the financial intermediaries (Banks and MFE) generally come from the granted loans. The creation of the quantity of money in circulation M2 by the Banks influences the quantity of credits granted by the Banks and EMF. The fact that credits cause intermediation margin is a good sign for foreign investors who could be potentials borrowers in order to produce significant profits. When credits are rather high, they can carry intermediation margin in Cameroon.

We will initially examine the causal relationship between Financial Intermediation and economic growth; then between economic growth and Financial Intermediation; between growth, monetary mass, intermediation margin and credits; between growth, credits, intermediation margin and monetary mass and finally between growth, credits, monetary mass and intermediation margin.

The causality table above shows that Financial Intermediation does not have a causal effect on growth in Cameroon. Refering to the p-values (less than 10\%), we see that there is no causal relationship between private credits (Ccmlt), Monetary mass (M2), intermediation margin (Mi) and Gross domestic product in Cameroon from 1977 to 2006. In 
other words FI doesn't granger cause economic growth in Cameroon. This result can be explained according to the literature by the restructuring of the banking system between 1980 to1992, bank overliquidity (e.g: Average liquidity ratio were $147 \%$ and $182 \%$ for banks in 1997 and MC $^{2}$ network in 2008 respectively), MFE's instability and poor growth environment in Cameroon. Actually, let us note that the Financial Intermediation must be strong enough to lead to growth.

In Cameroon, short term credit especially from MFE are low and do not make possible a durable foundation of mass production. Also, banks and MFEs are demanding as for the quality of the guarantee to be provided by the borrowers, not forgetting the fact that the high interest rates do not encourage the investors who risk averse. Thus these banks are overliquid whereas the level of investment through credits of the country is low. This non causality could also be explained by significant opening of the Cameroonian economy and by the perfect mobility of capital.

Moreover, the fact that FI does not have a causal link to growth could be also explained by the weakness of investment which does not carry economic growth. Let us also note that during the economic crisis that started in 1987 in Cameroon up to 1994, we recorded negative growth rates, which led to a fall of investment rate. Let us also note that administrative slowness and high taxes are likely to discourage investments which also discourage private credit.

Actually, the non causality effect of growth on FI in Cameroon is due to the consequences of the Structural Adjustment Program as well as the HIPC which put the country in a vast building site in all sectors, creating multiple fictitious jobs while increasing the income of a minority of Cameroonians. One can believe that the profit drawn from the investments is not invested to consolidate the existing economic activities. Thus a high level of economic growth does not create demand for certain financial instruments which find their answers in the development of the financial markets in Cameroon. One can also explain this non causality by the weight of the debt of the country. Indeed, one could think that profits from growth are swallowed by debt service.

There is no relationship of causality between GDP, M2, Mi and private credits. This situation could be explained by ungrowth environment, research of guarantee and slowness in the feasibility study of projects. It means that margin profit resulting from credit operations is not reinvested. The main reason of this rationing is the fight against the risk of anti selection and moral risk. Thus, uncertainty and information asymmetry which characterize markets, in particular credit market, leads financial institutions to rationate credits.

There is a causal relationship between credit (Ccmlt), M2 and Mi. This is explained by the fact that profits realised by the financial intermediaries (Banks and MFE) generally come from the granted loans. The creation of the quantity of money in circulation M2 influences the quantity of credits granted by the Banks and EMF. The fact that credits cause intermediation margin is a good sign for foreign investors who could be potentials borrowers in order to produce significant profits. When credits are rather high, they can carry intermediation margin in Cameroon. On the other hand, a relationship of causality between GDP and the intermediation margin (Mi) hardly exist because its $\mathrm{p}$-value is greater than 0.1 .

\section{Summary and Implications}

This article at the same time offers an empirical relativisation of the concept "intermediate market economy" and an illustration of the importance gained in recent years by the capital market. The econometric software Eviews enables us to carry out the different regressions. The Granger causality test of Toda-Yamamoto shows that Financial Intermediation does not have a causal effect on economic growth in Cameroon, contrary to several empirical studies which testify that it is FI that causes growth. This could be explained by unproductive investments (which are centered on the means and not the results), corruption and especially the diversions of funds in the attribution of government contracts which brings a bad quality of realization, or the period of study which would be very large and the effects are felt on the results. This disappearance is due to the fact that the socio-economic environments in which Banks and MFE as well as the amounts of the deposits and credits are differents. It should be noted that, Goldsmith in 1969, recognized that there is a link between the long run growth rate of the economy and the level of the evolution of financial sector.

\section{References}

Barnes. (2001). Micro Finance Program Clients and impact: An Assessment of Zambuko Trust, Zimbabwe, USAID-AIMS paper. Washington, D.C.

Barro, R., \& Sala-I-martin. (1996). La Croissance Economique. Paris: Ediscience International.

Biales, Ch. (2006). L'Intermédiation Financière, Septembre 2006. 
Bomba, J. (2003). Sommet du Micro crédit: Combattre la Pauvreté dans le monde à travers le Micro crédit, Le Défi des Pauvres, Octobre $2003 \mathrm{~N}^{\circ} 005$, Press-book Communication, p.26.

Brouillet, A. (2004). Micro finance et Lutte Contre la Pauvreté: Regard du Réseau impact.

Cerise \& CGAP. (2005). Les Performances Financières contre balancées par les performances sociales zoom sur l'initiative «SPI» social performance, indicor http/finsol.Socioeco.org.

Cheston, Susy, Khun L. \& Rogaly. (1996). Relation Genre et Micro Financement: Allocation Interne des Ressources des Ménages et Capacités des Femmes Pauvres à Développer des Activités Commerciales, Women's World Banking, pp.1-10.

Christen, J., Gulde, A., \& Patillo, C. (2006). Atouts potentiels: Finances et Développement, Décembre, Washington, FMI.

COBAC. (2002). Recueil des Textes Relatifs à l'Exercice des Activités de Micro Finance, Département de Micro Finance, $78 \mathrm{p}$.

Creusot, A.C. (2006). L’Etat des lieux de la Micro Finance au Cameroun, BIM N09, Mai 2006.

Demirgüc-Kunt, A., \& Levine, R. (1996). Stock Market Development and Financial Intermediaries: Stylized Facts. World Bank Economic Review, 19-26.

Goldsmith, R.W. (1969). Financial Structure and Development. New Haven: Yale University Press.

Johson. (1998). Synoptic View, IAAE, Eighteennth proceedings, Grower.

Kamajou, F., \& Baker, C.B. (1980). Reforming Cameroon's Credit Program: Effects on Liquidity Management by Small Farm Borrowers. American Agricultural Economics Association, 62(4).

Khan, A. (2000). The Finance and Growth Nexus, Federal Reserve. Bank of Philadelphia Business Review, 3-14.

King, R.G., \& Levine, R. (1993b). Finance and Growth: Schumpeter Might be Right. The Quarterly Journal of Monetary Economics, 108(3), 717-737.

Koffi, A. (1999). Role of Microcredit in eradication of poverty, Nations Unies. Report of the Secretary General, UN.

Labie, M. (1999). La Micro Finance en question: limites et Choix organisationnels, ed. Luc Pires, Bruxcelle.

Levine, R. (1996). Financial Development and Economic Growth. Policy Research Paper 1678, The World Bank.

Levine, R., \& Renelt, D. (1992). A Sensitivity Analysis of Cross- Country Growth Regressions. The American Economic Review, 82(4), 942-963.

Marion, P. (1990). Credit Union Achievements in Developing Countries. Yearbook of Cooperative Enterprise, Plunkett Foundation, Londres.

Mckinnon, R.I. (1973). Money and Capital in Economic Development. The Brookings Institution, Washington, DC.

Moutie, G.V. (2008). La Performance des Etablissements de Micro Finance par l'Approche Institutionnelle: le cas des $\mathrm{MC}^{2}$ à l'Ouest,Cameroun, Thèse de Master of Science, Université de Dschang, Juin 2008.

Nations Unies. (1999). Role of Microcredit in eradication of Poverty, Report of the Secretary General, UN.

Pagano, M. (1993). Financial Markets and Growth an overview. European Economic Review, (37), 613-622.

PNUD. (1998). Rapport sur le Développement Humain, la Pauvreté au Cameroun.

Retrieved 2006, from forum.europa.eu.int/irc/dsis/nfaccount/info/data/esa95/fr/efr00077.htm.

Retrieved from www.animhaiti.com, Rapport annuel d'activités 2005.

Retrieved from www.fimarkets.com, Marché financier, informatique et finance de marché, Cartapanis A. les marchés financiers internationaux, pp.80-85.

Retrieved from www.imf.org, Lutter contre la pauvreté dans les pays en développement, pp. 8-10.

Roubini \& Sala-I-martin. (1992). Financial Repression and Economic Growth. Journal of Development Economics, 39, 5-30.

Susy, C., \& Khun, L. (2006). Measuring Transformation: Assessing and Improving the Impact of Micro credit, pp.24-26. 